\title{
Characterization and Evaluation of Land Resources for Management of Barela Village in Seoni district, Madhya Pradesh using High Resolution Satellite Data and GIS
}

\author{
Akash A. Borse ${ }^{1}$, M.S.S. Nagaraju*, Benukantha Dash, Nisha Sahu, \\ Sagar N. Ingle ${ }^{1}$ and Rajeev Srivastava \\ ICAR-National Bureau of Soil Survey and Land Use Planning, Nagpur-440033, Maharashtra, India \\ ${ }^{\prime}$ Dr. Panjabrao Deshmukh Krishi Vidyapeeth, Akola- 444104, Maharashtra, India
}

\begin{abstract}
The present investigation was carried out in Barela village of Seoni district, Madhya Pradesh to characterize, classify and evaluate the land resources using IRS-LISS-IV and GIS. Five major landforms namely Plateau, escarpments, mound, pediment and alluvial plain were identified and delineated. Based on image characteristics, seven land uses/ land cover classes viz., (single crop, double crop, degraded forest, wasteland, river, waterbody and habitation) were identified. Five slope classes viz., very gently sloping (1-3\%), gently sloping (3-5\%), moderately sloping (5-10\%), strongly sloping (10-15\%) and steeply sloping ( $15-25 \%)$ lands have been identified using Cartosat-1 DEM (30 m resolution) and topographic information. Five soil series (Barela-1, Barela-2, Barela-3, Barela-4 and Barela-5) were tentatively identified and mapped based on landform-soil relationship. Soils, in general, were shallow to moderately deep, moderately well to well drained with moderate to severe erosion and clayey in texture. The soils are neutral to slightly alkaline in reaction and non-saline and qualify for Lithic Ustorthents/ Typic Haplustepts/ Typic Haplusterts at subgroup level. The soils were grouped under land capability sub-classes IIs, IIIes, IVst and VIst and land irrigability sub-classes $2 \mathrm{~s}$, 3 st and 4st. The soils of Barela-4 are moderately suitable for growing gram, soybean, maize and pigeonpea. The soils of Barela-5 are highly suitable for growing pigeonpea and moderately suitable for growing gram, soybean and maize. Soils of Barela-1, Barela-2 and Barela-3 are not suitable for growing gram, soybean, maize and pigeonpea. Various soil and water conservation measures and alternate land use options have been suggested based on land resources information generated for management of land resources in the village.
\end{abstract}

Key words: Soil characterization, land capability, land irrigability, suitability for crops, remote sensing, GIS

\section{Introduction}

Sustainable management of land resources is essential for food security, maintenance of environment and general well being of the people. Indiscriminate use of resources coupled with lack of management has, however, led to degradation echoing the concern of planners, researchers and farmers.. It is also essential to enhance the soil productivity to meet the future demand. The characterization and mapping of different types of soils and their interpretation attains greater importance. Soil survey provides an accurate and scientific inventory of soils, their kind and nature, and extent of distribution so that one can make prediction about their

*Corresponding author: (Email: mssnagaraju@yahoo.com) 
characteristics and potentialities. Remote sensing is a powerful tool to characterize the land resources in real time and in cost effective manner. The digitally interpreted remotely sensed image provide a wealth of information of large areas and permit lithological discrimination, identification of different landform, soils and land use/land cover patterns which help in land resource characterization and their management. Several studies have been initiated on potential use of IRS satellite data for soil mapping at different scales using remote sensing and GIS (Srivastava and Saxena 2004; Patil et al., 2010; Pachpor et al., 2012; Nagaraju et al. 2014).

The Seoni district of Madhya Pradesh is experiencing frequent erratic rainfall with continuous depletion of vegetative cover and increase in soil erosion with low crop productivity. The information on detailed characterization of soils, soil related constraints and potentials and soil fertility at village-level is lacking. Therefore, the present investigation has been planned to characterize and map the soils of Bareli village in Seoni district of Madhya Pradesh for land resources management.

\section{Materials and Methods}

Study area

The Barela village in basaltic terrain, lies between $22^{\circ} 32^{\prime} 47^{\prime \prime}$ to $22^{\circ} 34^{\prime} 22^{\prime \prime} \mathrm{N}$ latitudes and $79^{\circ} 44^{\prime}$ $51^{\prime \prime}$ to $79^{\circ} 46^{\prime} 49^{\prime \prime} E$ longitudes and covers an area of 480 ha in Dhanora block, Seoni district, Madhya Pradesh (Fig. 1). Barela village was divided into five major landforms viz. plateau (P), escarpments (E), isolated mounds (M), pediments (D) and alluvial plain (A). The elevation of the area ranges from 503 to $564 \mathrm{~m}$ above mean sea level (MSL). The area is associated with very gently sloping (1-3\%) to strongly sloping (15-25\%) lands. The climate is mainly dry sub-tropical with mean annual temperature of $28.4^{\circ} \mathrm{C}$ and mean annual rainfall of $1100 \mathrm{~mm}$. The area qualifies for ustic soil moisture regime and hyperthermic soil temperature regime, respectively. The natural vegetation comprises of teak (Tectona grandis), babul (Acacia spp.), palas (Butea frandosa), charoli (Buchanania lanzan), ber (Ziziphus jujuba) etc. The major crops are paddy (Oriza sativa), pigeonpea (Cajanus cajan), maize (Zea mays) and safflower (Carthamus tinctorius) in kharif and wheat (Triticum aestivum) and gram (Cicer arietinum) in rabi under irrigation or stored moisture. Mango and Guava are the main fruit crops of the area.

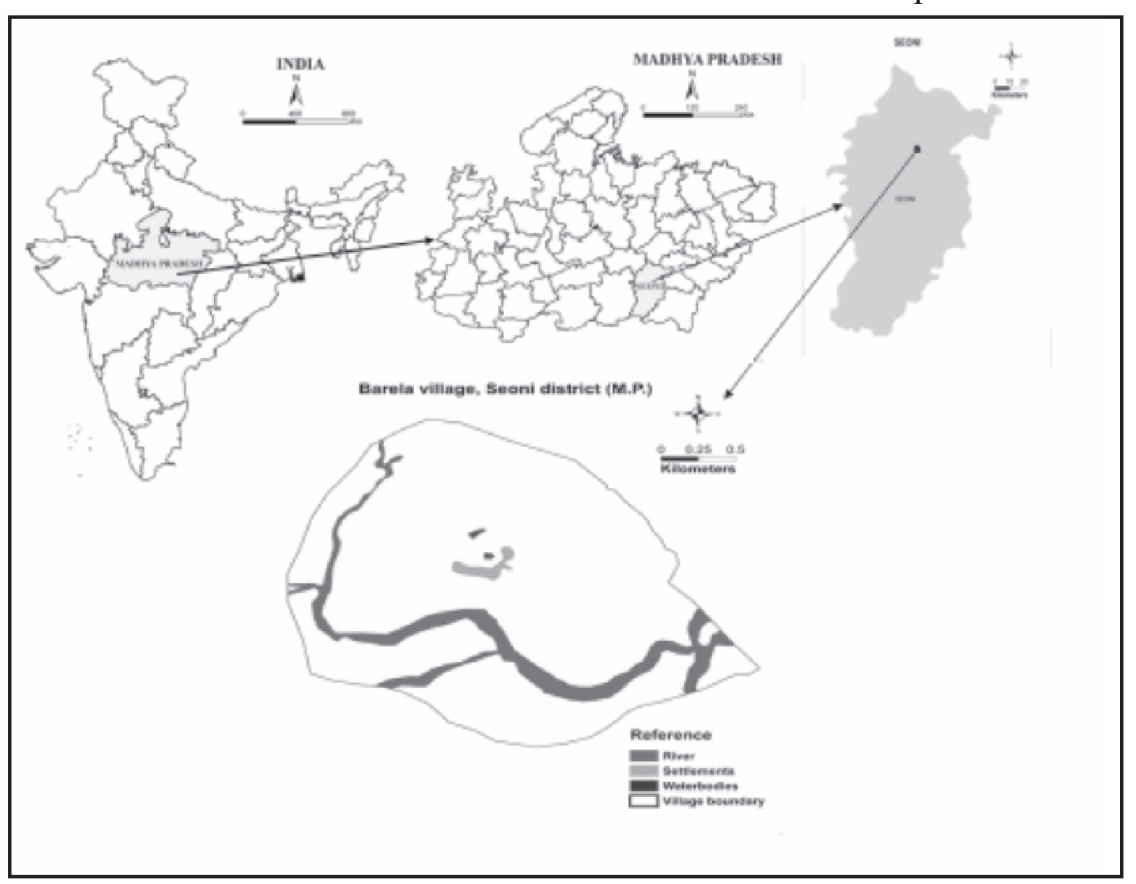

Fig. 1. Location of study area 
Datasets used

Digital data of Cartosat-1 sharpened IRS-P6 LISS-IV data of (November, 2013) with a spatial resolution of $5.8 \mathrm{~m}$ along with LISS-III (March, 2012) with a spatial resolution of $23.5 \mathrm{~m}$ was used. The standard False Colour Composite (FCC) was generated with the combination of green, red and Near Infra Red (NIR) bands. Cartosat-1 Digital Elevation Model (DEM) (30 m resolution) was used for generation of slope map. Survey of India (SoI) Toposheet No. 55 N/10 and $55 \mathrm{~N} / 14$ (1:50000 scale) was used to collect topographic and location information. The toposheet was used to prepare base map for delineation of landforms, slope and drainage.

\section{Methodology}

The land use/ land cover map was generated by visual interpretation of geocoded satellite data based on tone, texture, pattern, shape and size. Using the interpreted maps for landforms, slope and land use/land cover maps, the area was traversed and verified. Twenty eight pedons representing different landform units were studied. Site and soil characteristics like slope, stoniness, erosion, colour, texture, structure etc. were recorded (Soil Survey Division Staff 2000)

Nearly $2.0 \mathrm{~kg}$ of representative soil sample from each horizon from representative pedons were collected for laboratory studies. Soil clods were collected from different horizons for the determination of bulk density. The analysis of physical, chemical and nutrient properties of collected samples were carried out using standard procedures (Black 1965; Jackson 1967; Lindsay and Norvell 1978). The soils were classified as per Soil Taxonomy (Soil Survey Staff 2003) and grouped into different capability sub-classes (Klingebiel and Montgomery 1961), land irrigability sub-classes (AIS\&LUS 1971). The soil-site suitability analysis (NBSS\&LUP 1994) was done for evaluating the suitability of different mapping units for paddy, maize, soybean, sorghum, pigeonpea and chickpea. ArcGIS software was used for generation of various spatial thematic maps.

\section{Results and Discussion}

Present land use/land cover

Based on image characteristics, the major land use/land cover identified are cultivated land, wasteland, degraded forest, habitation and water bodies (Fig.2a). Cultivated land is again delineated into single and double crop based on temporal satellite data. The extent of area under different land utilization types indicates that cultivated land occupies 58.3 per cent of the total geographical area (TGA) of which 32.1 per cent is under single crop. The area under double crop occupies 26.2 per cent of the cultivated area, where, assured/protective irrigation is available. The degraded forest land occupies 9.5 per cent of the total geographical area (TGA). Wasteland occupies 21.4 per cent of the total geographical area and river occupies 9.6 per cent of the total geographical area (TGA). Waterbodies and habitation occupy 0.1 and 0.7 per cent area, respectively.

Slope

Five slope classes viz., very gently sloping (1$3 \%$ ), gently sloping (3-5\%), moderately sloping (5$10 \%)$, strongly sloping (10-15\%) and steeply sloping ( 15-25\%) lands have been identified (Fig. 2b). The major area is under gently sloping land (36.5\% of TGA). Very gently sloping, moderately sloping, strongly sloping and steeply sloping land occupy $30.5,13.2,1.2$ and 8.3 per cent of TGA, respectively.

\section{Landform-soil relationship}

Based on visual interpretation of Cartosat-1 merged IRS-P6 LISS-IV data along with SOI toposheet and subsequent ground truth verification, five major landform viz. plateau (P), escarpments (E), isolated mounds (M), pediments (D) and alluvial plain (A) were identified. These landform were further sub-divided based on slope and land use/land cover (Table 1; Fig. 2c). Five soil series (Barela-1, Barela-2, Barela-3 Barela-4 and Barela-5) were tentatively identified in different landform units and mapped as phases of soil series at 1:10000 scale (Fig.2d) after establishing landform-soil relationship (Table 2). 
Table 1. Landform and their description

\begin{tabular}{|c|c|c|}
\hline $\begin{array}{c}\text { Map } \\
\text { Unit No. }\end{array}$ & $\begin{array}{l}\text { Landform } \\
\text { symbol }\end{array}$ & Landform description \\
\hline 1 & $\mathrm{P} 2 \mathrm{~s}$ & $\begin{array}{l}\text { Very gently sloping plateau having bluish green and pink tone with diffuse } \\
\text { checkerboard pattern }\end{array}$ \\
\hline 2 & $\mathrm{P} 3 \mathrm{~s}$ & $\begin{array}{l}\text { Very gently sloping plateau having bluish green and pink tone with diffuse } \\
\text { checkerboard pattern }\end{array}$ \\
\hline 3 & $\mathrm{P} 3 \mathrm{w}$ & Very gently sloping plateau having bluish -green and pink tone with medium texture \\
\hline 4 & $\mathrm{P} 4 \mathrm{w}$ & moderately sloping plateau having bluish -green and pink tone with medium texture \\
\hline 5 & E5df1 & Strongly sloping escarpment having bluish -green and pink tone with medium texture \\
\hline 6 & E6df2 & $\begin{array}{l}\text { Moderately steep to steep sloping escarpment having bluish -green and pink tone } \\
\text { with medium texture }\end{array}$ \\
\hline 7 & $\mathrm{D} 2 \mathrm{~s}$ & $\begin{array}{l}\text { Very gently sloping pediment having bluish green and pink tone with diffuse } \\
\text { checkerboard pattern }\end{array}$ \\
\hline 8 & $\mathrm{D} 3 \mathrm{~s}$ & $\begin{array}{l}\text { Gently sloping pediment having bluish green and pink tone with diffuse } \\
\text { checkerboard pattern }\end{array}$ \\
\hline 9 & $\mathrm{D} 4 \mathrm{~s}$ & $\begin{array}{l}\text { Moderately sloping pediment having greenish blue with diffuse checker board } \\
\text { pattern }\end{array}$ \\
\hline 10 & $\mathrm{D} 2 \mathrm{~d}$ & Very gently sloping pediment having dark red tone with bold checker board pattern \\
\hline 11 & D3d & Gently sloping pediment having Dark red with bold checker board pattern \\
\hline 12 & $\mathrm{D} 4 \mathrm{~d}$ & strongly sloping pediment having dark red tone with bold checker board pattern \\
\hline 13 & D3w & $\begin{array}{l}\text { Gently sloping pediment having greenish blue tone with pink patches, medium } \\
\text { texture }\end{array}$ \\
\hline 14 & $\mathrm{D} 4 \mathrm{w}$ & $\begin{array}{l}\text { Moderately slo ping pediment having bluish green and pink tone with diffuse } \\
\text { checkerboard pattern }\end{array}$ \\
\hline 15 & $\mathrm{M} 3 \mathrm{w}$ & $\begin{array}{l}\text { Gently sloping mound having medium red to light red tone with some bluish } \\
\text { patches, medium texture }\end{array}$ \\
\hline 16 & D5f2 & $\begin{array}{l}\text { Strongly sloping pediment having medium red to light red tone with some bluish } \\
\text { patches, medium texture }\end{array}$ \\
\hline 17 & $\mathrm{M} 4 \mathrm{w}$ & $\begin{array}{l}\text { Moderately sloping isolated mound having greenish blue tone with pink patches, } \\
\text { medium texture }\end{array}$ \\
\hline 18 & $\mathrm{~A} 2 \mathrm{~d}$ & Very gently sloping alluvial plain having dark red with bold checker board pattern \\
\hline
\end{tabular}


Table 2. Landform-soil relationship

\begin{tabular}{|c|c|c|c|}
\hline Landform & Soil Series & Soil Characteristics & Soil Taxonomy \\
\hline Plateau top & Barela-1 & $\begin{array}{l}\text { Shallow, moderately well drained, very dark } \\
\text { greyish brown (10YR } 3 / 2 \mathrm{M}) \text {, clay soils } \\
\text { underlain by hard rock with moderate erosion }\end{array}$ & $\begin{array}{l}\text { Clayey, smectitic, } \\
\text { hyperthermic Lithic } \\
\text { Ustorthents }\end{array}$ \\
\hline Escarpment & Barela-2 & $\begin{array}{l}\text { Moderately deep, well drained, dark greyish } \\
\text { brown (10YR3/1), clay soils texture with severe } \\
\text { erosion }\end{array}$ & $\begin{array}{l}\text { Fine, smectitic, } \\
\text { hyperthermic Typic } \\
\text { Haplustepts }\end{array}$ \\
\hline Pediment & Barela-3 & $\begin{array}{l}\text { Very shallow, well drained, dark brown } \\
(7.5 \mathrm{YR} 3 / 2) \text {, clay loam soils with moderate } \\
\text { erosion }\end{array}$ & $\begin{array}{l}\text { Clayey, smectitic, } \\
\text { hyperthermic Lithic } \\
\text { Ustorthents }\end{array}$ \\
\hline Pediment & Barela-4 & $\begin{array}{l}\text { Deep, well drained, very dark grey (10YR3/1) } \\
\text { to brown (10YR4/3), clay soils texture with } \\
\text { severe erosion }\end{array}$ & $\begin{array}{l}\text { Fine, smectitic, } \\
\text { hyperthermic Typic } \\
\text { Haplusterts }\end{array}$ \\
\hline Alluvial plain & Barela-5 & $\begin{array}{l}\text { Very deep, moderately well drained, black } \\
(10 \mathrm{YR} 2 / 1) \text { to very dark grayish brown } \\
(10 \mathrm{YR} 3 / 2) \text {, clay soils with slight } \\
\text { erosion. }\end{array}$ & $\begin{array}{l}\text { Very-fine, smectitic, } \\
\text { hyperthermic Typic } \\
\text { Haplusterts }\end{array}$ \\
\hline
\end{tabular}




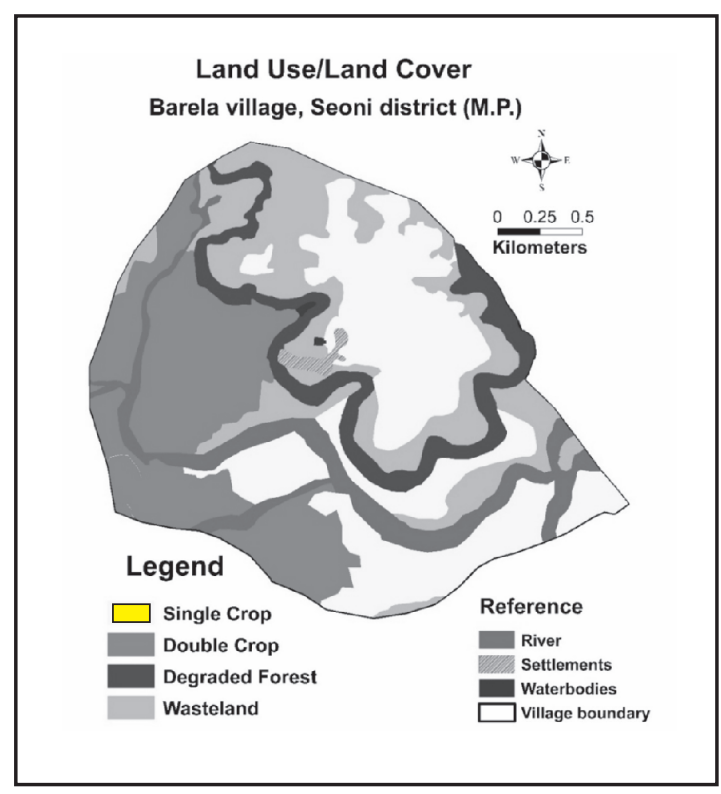

Fig. 2a land use / land cover

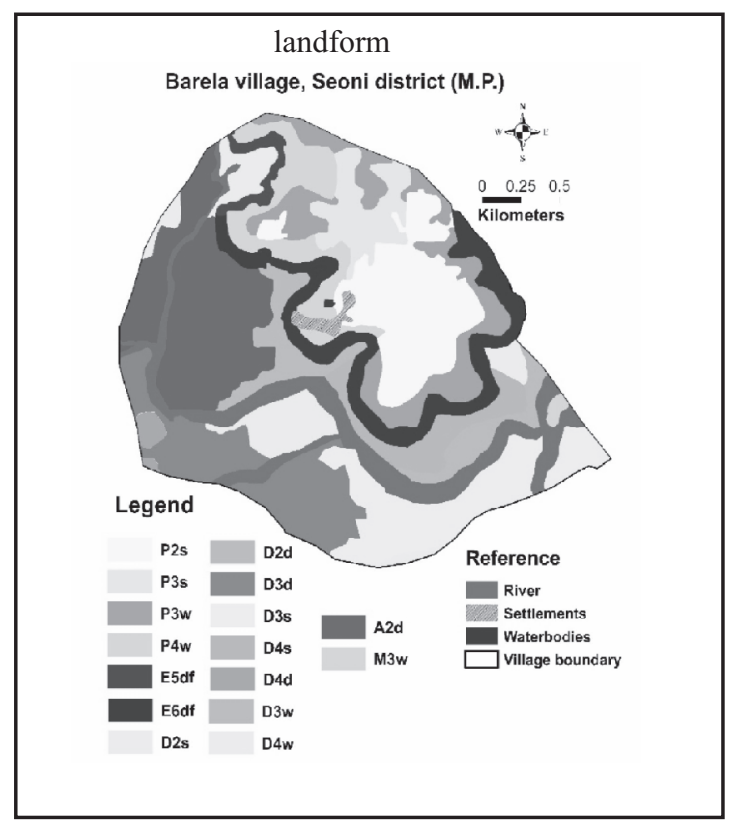

Fig. 2c Landform

\section{Soil physical properties}

The data (Table 3) indicated that the soils have higher proportion of clay compared to sand and silt. The sand, silt and clay contents in soils of plateau varied 32.1, 26.2 and 41.9 per cent, respectively and 19.4 to 23.5 , 19.4 to 23.3 and 53.2 to 61.2 per cent, respectively in the soils of escarpment. The soils of pediment had sand, silt and clay content ranging from 17.1 to $39.5,16$ to 28 and 36 to 58.3 per cent, respectively.The sand, silt and clay

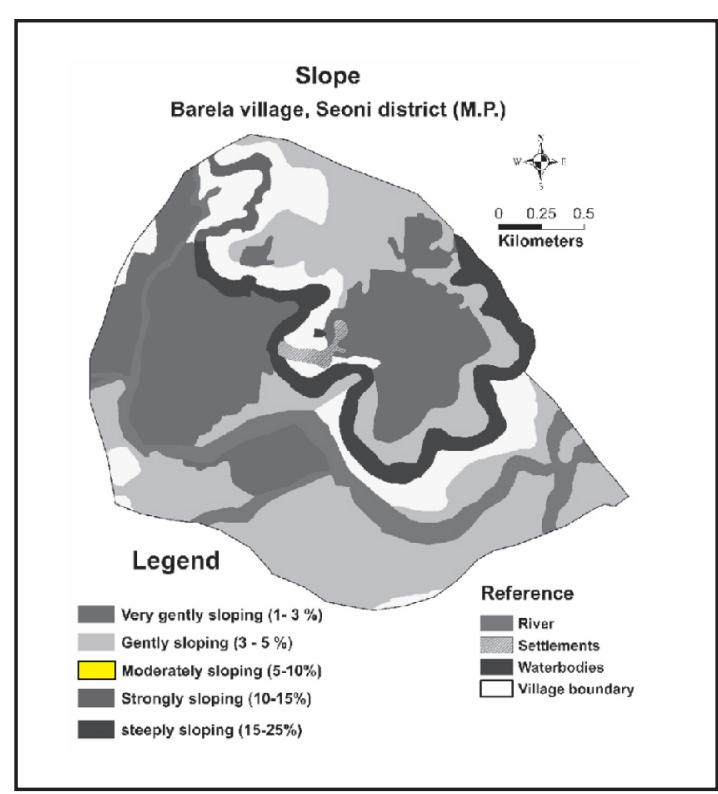

Fig. 2b slope

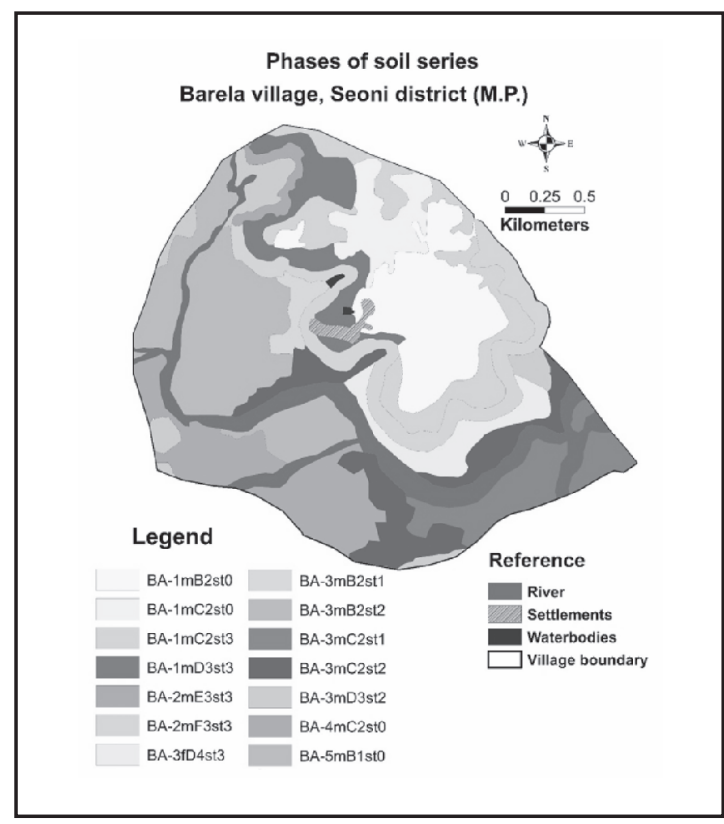

Fig. 2d Phases of soil series

contents in soils of alluvial plain varied from 2.1 to 13.8 , 21.2 to 34 and 52.2 to 75.2 per cent, respectively. The bulk density of surface and sub-surface soils varies from 1.32 to 1.69 and 1.42 to $1.69 \mathrm{Mgm}^{-3}$, respectively. Bulk density of sub-surface horizons was higher than that of surface horizons which might be due to compaction caused by the overburden of surface layers (Ahuja et al. 1988) and lower bulk density in surface layer may be due to cultivation, organic matter and biotic activities (Rao etal.2008). 
Table 3. Physical properties of soils

\begin{tabular}{|c|c|c|c|c|c|}
\hline Horizon & $\begin{array}{l}\text { Depth } \\
\text { (cm) }\end{array}$ & $\begin{array}{c}\text { Sand } \\
2-0.05(\mathrm{~mm}) \\
(\%)\end{array}$ & $\begin{array}{c}\text { Silt } \\
0.05-0.002(\mathrm{~mm}) \\
(\%)\end{array}$ & $\begin{array}{c}\text { Clay } \\
<0.002(\mathrm{~mm}) \\
(\%)\end{array}$ & $\begin{array}{c}\text { BD } \\
\left(\mathrm{Mgm}^{-3}\right)\end{array}$ \\
\hline \multicolumn{6}{|c|}{ Barela-1: Clayey, smectitic, hyperthermic Lithic Ustorthents } \\
\hline Ap & $0-15$ & 32.1 & 26.0 & 41.9 & 1.37 \\
\hline \multicolumn{6}{|c|}{ Barela- 2: Fine, smectitic, hyperthermic Typic Haplustepts } \\
\hline A & $0-17$ & 19.4 & 19.4 & 61.2 & 1.34 \\
\hline Bw1 & $17-34$ & 20.5 & 22.2 & 57.3 & 1.46 \\
\hline Bw2 & $34-51$ & 23.5 & 23.3 & 53.2 & 1.57 \\
\hline \multicolumn{6}{|c|}{ Barela-3: Clayey, smectitic, hyperthermic Lithic Ustorthents } \\
\hline Ap & $0-10$ & 36.0 & 28.0 & 36.0 & 1.39 \\
\hline \multicolumn{6}{|c|}{ Barela-4: Fine, smectitic, hyperthermic Typic Haplusterts } \\
\hline AP & $0-18$ & 30.3 & 27.4 & 42.3 & 1.34 \\
\hline $\mathrm{Bw}$ & $18-38$ & 17.1 & 24.6 & 58.3 & 1.42 \\
\hline Bss1 & $38-55$ & 21.9 & 27.3 & 50.8 & 1.48 \\
\hline Bss2 & $55-75$ & 26.1 & 22.0 & 51.9 & 1.56 \\
\hline Bss3 & $75-101$ & 39.5 & 16.0 & 44.5 & 1.63 \\
\hline \multicolumn{6}{|c|}{ Barela-5: Very-fine, smectitic, hyperthermic Typic Haplusterts } \\
\hline $\mathrm{AP}$ & $0-18$ & 4.4 & 24.4 & 71.2 & 1.32 \\
\hline $\mathrm{Bw}$ & $18-42$ & 3.6 & 21.2 & 75.2 & 1.46 \\
\hline Bss1 & $42-76$ & 3.0 & 22.0 & 75.0 & 1.55 \\
\hline Bss2 & $76-102$ & 2.1 & 23.0 & 74.9 & 1.61 \\
\hline Bss3 & $102-132$ & 3.0 & 22.0 & 75.0 & 1.65 \\
\hline 2Bss4 & $132-150$ & 13.8 & 34.0 & 52.2 & 1.69 \\
\hline
\end{tabular}

\section{Chemical properties}

Soils of the village are neutral to alkaline with $\mathrm{pH}$ values ranging from 6.5 to 7.9. The organic carbon content in soils ranged from 0.17 to 1.92 per cent in different horizons (Table 4). In general, the organic carbon content decreased gradually with depth, mainly due to the accumulation of plant residues on the soil surface. The calcium carbonate content varied from 1.45 to 5.3 per cent through depth. The exchangeable calcium content of the soils ranged from 20 to $34.5 \mathrm{cmol}\left(\mathrm{p}^{+}\right) \mathrm{kg}^{-1}$ soil being higher in soils of Barela-4 and Barela-5. Exchangeable magnesium content of the surface soils ranged from 16.8 to $21.5 \mathrm{cmol}\left(\mathrm{p}^{+}\right) \mathrm{kg}^{-1}$ soil. Exchangeable sodium ranged from 0.57 to $0.58 \mathrm{cmol}$ (p) $\mathrm{kg}^{-1}$ soil. Exchangeable potassium ranged from 0.15 to $0.21 \mathrm{cmol}\left(\mathrm{p}^{+}\right) \mathrm{kg}^{-1}$ soil. The exchangeable cations were found in the order of $\mathrm{Ca}^{2+}>\mathrm{Mg}^{2+}>\mathrm{Na}^{+}>\mathrm{K}^{+}$ indicating the presence of calcium bearing minerals in parent rocks. Similar result was reported by Sarkar et al. (2001). Cation exchange capacity (CEC) of surface soils ranged from 39.1 to $62.6 \mathrm{cmol}\left(\mathrm{p}^{+}\right) \mathrm{kg}^{-1}$ soil.

\section{Soilfertility}

The available nitrogen content of the surface soils ranged from 107 to $390 \mathrm{~kg} \mathrm{ha}^{-1}$ and it was low in soils of Barela-1, Barela-2 and Barela-3 (Table 4). The available phosphorus in the surface soils varied from 7.9 to $34.3 \mathrm{~kg} \mathrm{ha}{ }^{-1}$ being low in soils of Barela-1, moderately high in soils of Barela-2 and Barela-5 and high in soils of Barela-3 and Barela-4. Available potassium content in the surface soils varied from $342.4 \mathrm{~kg} \mathrm{ha}^{-1}$ to $492.8 \mathrm{~kg}$ ha 1. DTPA- Fe ranged from 11.1 to $33.6 \mathrm{mg} \mathrm{kg}^{-1}$ (Table 4) which is above the critical value of $4.5 \mathrm{mg} \mathrm{kg}^{-1}$ (Lindsay and Norvell 1978). The DTPA-Mn ranged from 10.1 to $43.1 \mathrm{mg} \mathrm{kg}^{-1}$ and was above the critical limit $3.0 \mathrm{mg} \mathrm{kg}^{-1}$ (Takkar et al. 1989). DTPA-Cu varied from 2.3 to $6.4 \mathrm{mg} \mathrm{kg}^{-1}$ and higher than the critical value of 0.2 mg kg-1 (Katyal and Randhawa 1983). The DTPA-Zn ranged from 0.15 to $0.59 \mathrm{mg} \mathrm{kg}^{-1}$ and was below the critical level of $0.6 \mathrm{mgkg}^{-1}$ as suggested by Katyal and Randhawa(1983). 


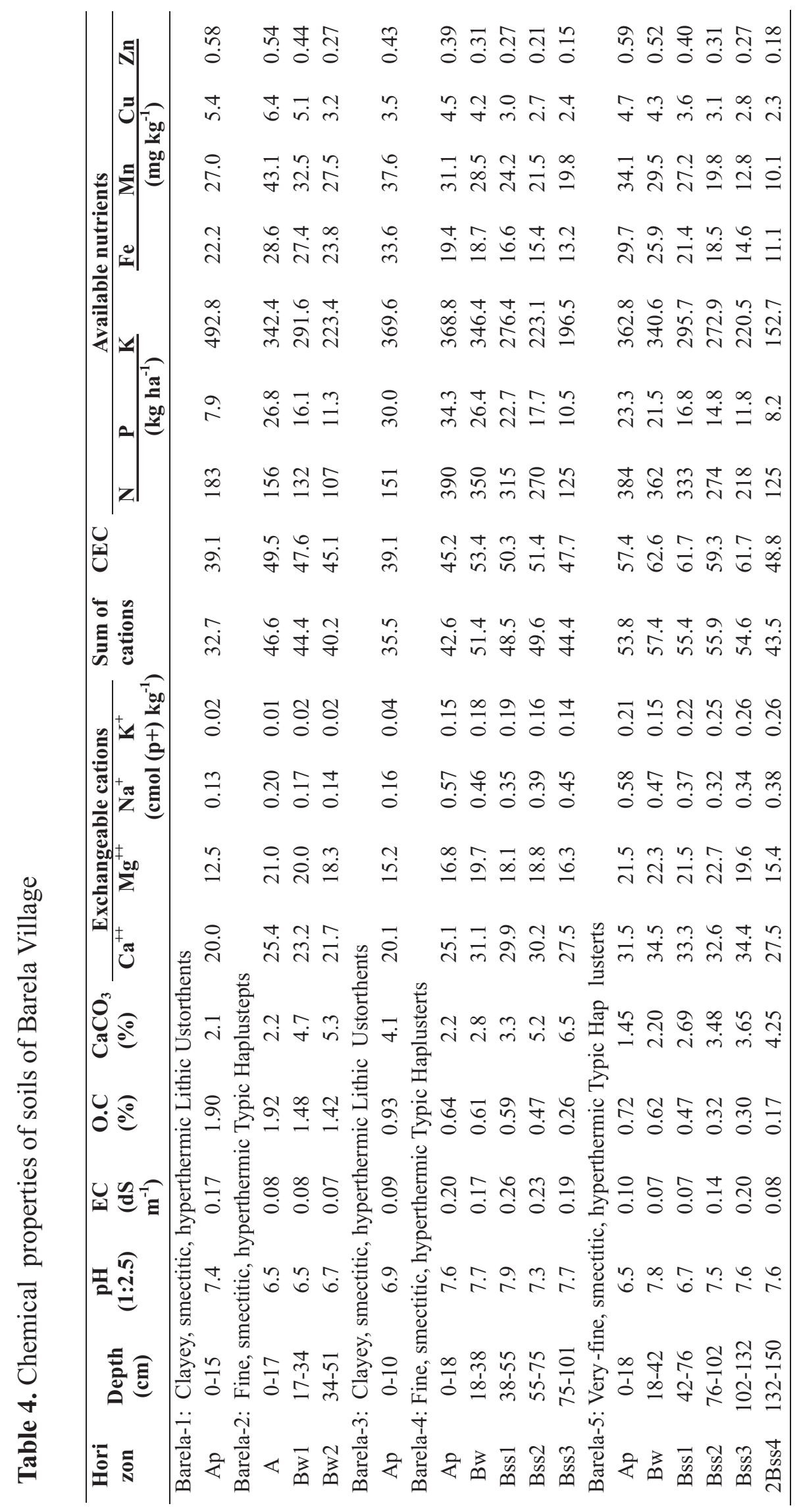


Land capability, land irrigability and soil suitability for crops

Based on the criteria of land capability groupings, four land capability sub-classes viz. IIs (14.5 $\%$ of TGA), IIIes ( $9.7 \%$ of TGA), IVst (55.9 \% of TGA) and VIst (9.5\% of TGA) have been identified (Table 5; Fig. 3a). The soils of Barela-1, and Barel-3 are fairly good cultivable lands (IVst) with severe limitations of soil depth, slope and erosion. The soils of Barela-2 (VIst) are non-arable lands mainly under degraded forest with strong and steeply sloping lands with severe limitation of soil depth, slope and erosion. The soils of Barela-4
(IIIes) are moderately good cultivable lands with moderate limitations due to soil depth, slope and erosion. The soils of Barela-5 (IIs) are good cultivable lands with high smectitic clay posing drainage problem

Land irrigabilty evaluation indicated that soils of Barela-1, Barela-2, and Barela-3 have very severe limitations of soil depth and texture and hence grouped under land irrigability sub-class 4 st. The soils of Barela4 are grouped under 3st with severe limitations of slope, surface texture. The soils of Barela-5 are grouped under $2 \mathrm{~s}$ with moderate limitations of soil texture and soil drainage (Table 5; Fig. 3b).
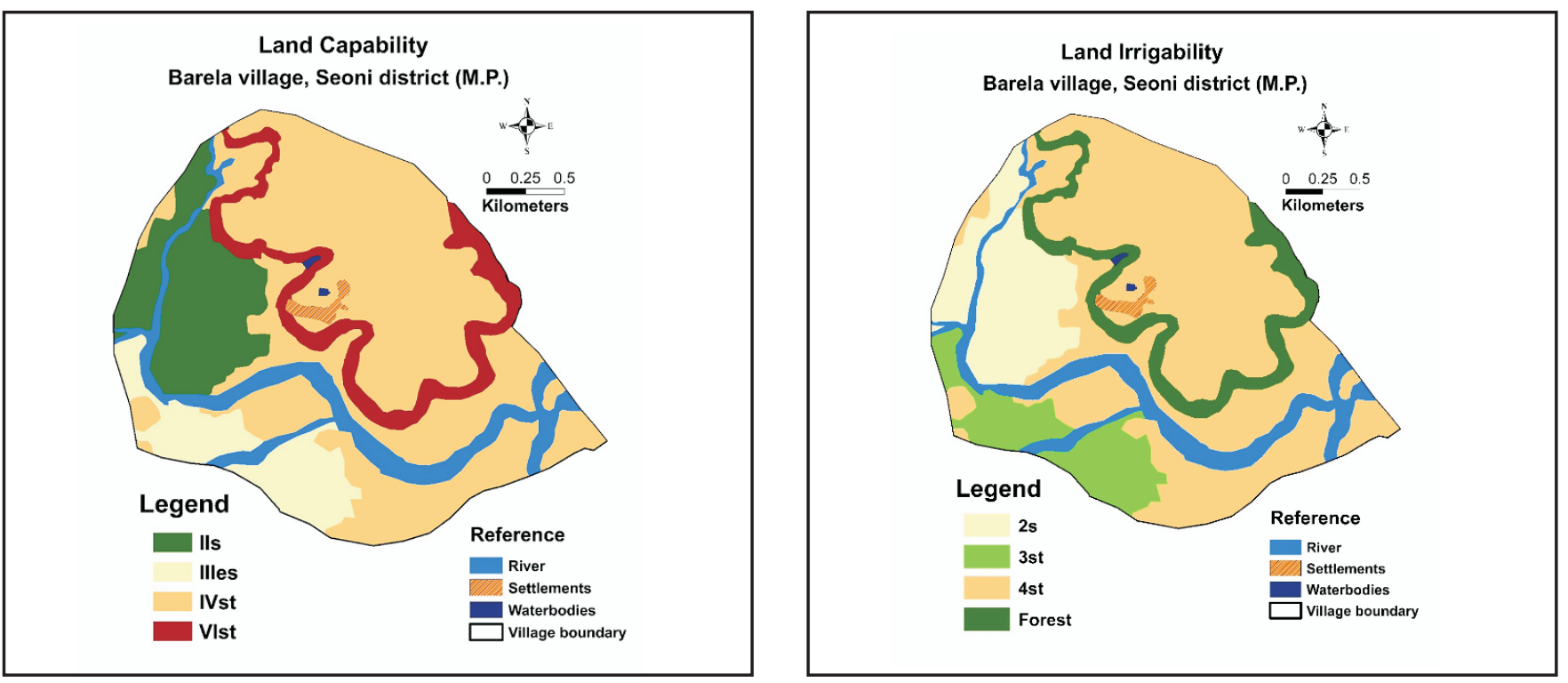

Fig. 3. Land capability (a), land irrigability (b) classification

The suitability evaluation for gram, soybean, maize and pegionpea (Table 5; Fig. 4) indicated that the soils of Barela-5 were highly suitable for growing pigeonpea and moderately suitable for gram, soybean and maize. The soils of Barela- 4 are moderately suitable for gram, soybean, maize and pigeonpea. The soils of Barela-1, Barela-2 and Barela-3 are not suitable for these crops.

Table 5. Land capability, land irigability and suitability of soils for different crops

\begin{tabular}{lcccccc}
\hline Soils & $\begin{array}{c}\text { Land } \\
\text { capability }\end{array}$ & $\begin{array}{c}\text { Land } \\
\text { irrigability }\end{array}$ & Gram & Soybean & Maize & Pigeonpea \\
\hline Barela-1 & IVst & $4 s t$ & N1 & N1 & N1 & N1 \\
Barela-2 & VIst & $4 s t$ & N1 & N1 & N1 & N1 \\
Barela-3 & IVst & $4 s t$ & N1 & N1 & N1 & N1 \\
Barela-4 & IIIes & $3 s t$ & S2 & S2 & S2 & S2 \\
Barela-5 & IIs & $2 s$ & S2 & S2 & S2 & S1 \\
\hline
\end{tabular}



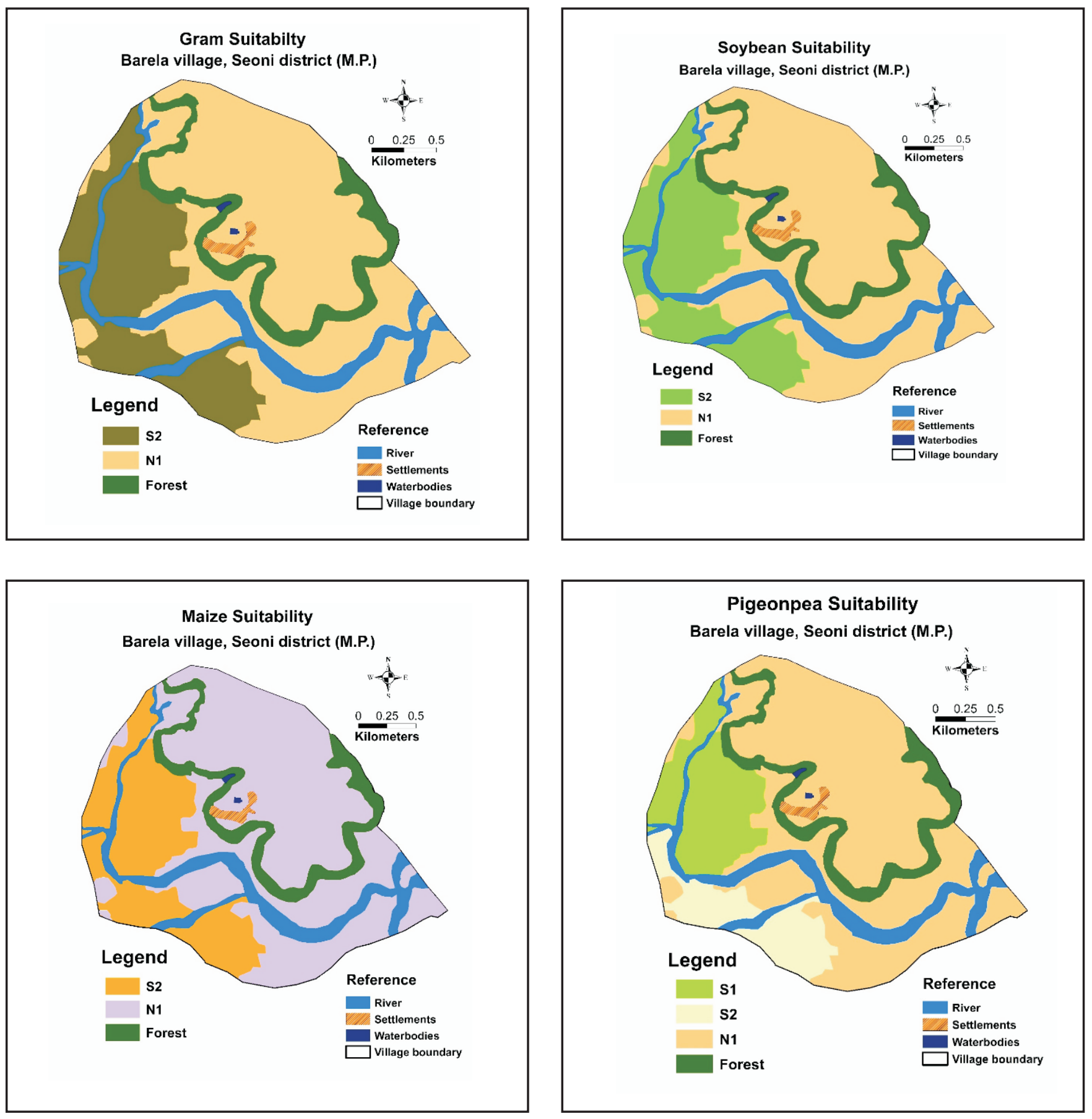

Fig. 4. Suitability of soils for a) gram b) soybean c) maize d) pigeonpea cultivation

\section{Land resources management}

The integration of landform, soil, present land use and slope maps under GIS environment has brought out the thirteen composite land units which lead to identify the areas for resource development and conservation. The suggested land use plan with suitable interventions includes agri-horticulture, agro-forestry, silvipasture and intensive cultivation.

The plateau with very shallow soils under single crop (Barela-1) has fairly good cultivated lands with severe limitations due to soil depth, slope and erosion. The soils also have very severe limitations of soil depth and texture for sustained use under irrigation. The soils 
of Barela-1 are low in available $\mathrm{N}$ and available $\mathrm{P}$ and very high in available $\mathrm{K}$. The soils are poor in soil productivity and severely eroded without any soil and water conservation measures. To improve the productivity in cultivated land units under single crop and wasteland, agri-horticulture with goosebery, guava, custard apple and drum stick may be adopted under integrated nutrient management and suitable soil and water conservation measures like contour bunding, gully plugging and water harvesting structures.

The escarpments having moderately deep soils (Barela-2) is under degraded forest and occur on strongly (10-15\%) and steeply sloping (15-25\%) lands with severe erosion with poor soil productivity. The area is suggested for afforestation and agroforestry with suitable tree species like gooseberry, guava, and custard apple to improve the productivity of these land units. Staggered contour trenches needs to be taken up to reduce the run-off and soil loss.

The very shallow and deep soils (Barela-3, Barela-4) associated with pediments are under single and double crop. The mapping units with shallow soils have fairly good cultivated lands with severe limitations due to soil depth, slope and erosion and also possess very severe limitations of soil depth and texture for sustained use under irrigation. The soils of Barela- 3 are low in available $\mathrm{N}$, high in available $\mathrm{P}$, very high in available $\mathrm{K}$ and deficient in available $\mathrm{Zn}$. The mapping units with soils of Barela-4 are low in available N, high in available $\mathrm{P}$, very high in available $\mathrm{K}$ and deficient in available $\mathrm{Zn}$. The soils are moderately eroded due to lack of soil and water conservation measures. The soils of Barela- 4 are moderately suitable of maize, pigeonpea, gram and soybean. Proper field bunding, gully plugging and contour bunding is needed to conserve soil and water. Agri-horticulture interventions like goose berry, guava, custard apple and drum stick and silvipasture systems with multi-purpose trees under integrated nutrient management needs be taken up in these land units to improve the productivity.

The very deep soils of alluvial plain (Barela-5) have moderate limitations for sustained use under irrigation. The soils are medium in available $\mathrm{N}$, moderately high in available $\mathrm{P}$, very high in available $\mathrm{K}$ and deficient in DTPA- Zn. The productivity of these soils may be improved by adopting integrated nutrient management and agronomic measures such as crop rotation with legumes, mixed cropping and vegetable cultivation.

\section{Conclusions}

Five major landform units viz. plateau top, escarpment, isolated mound, pediment and alluvial plain and five major land use/land cover viz. cultivated land, wasteland, degraded forest, habitation and water bodies were identified using high-resolution satellite data. Five slope classes namely very gently sloping (1-3\%), gently sloping (3-5\%), moderately sloping (5-10\%), strongly sloping (10-15\%) and moderately step to steep sloping (15-25\%) lands have been identified. Five soil series (Barela-1, Barela-2, Barela-3, Barela-4 and Barela-5) were tentatively identified and mapped as soil series at 1:10000 scales. Soils are shallow to very deep (shrinkswell soils) and have clay to clay loam texture. The soils are moderately well drained to well drain with moderate to severe erosion. The village has well to fairly good cultivable lands and minor to moderate limitations for sustained use under irrigation. The soil-site suitability evaluation indicated that soils are highly suitable to not suitable for growing pigeonpea, maize, gram and soybean with various interventions and soil and water conservation measures have been suggested to for better management of land resources in Barela village of Seoni district Madhya Pradesh.

\section{References}

Ahuja, P.A., Ojanuga, A.G., and Olsen, K.R. (1988). Soil landscape relationship in the Sokota-Rima basin. Journal of Hydrology 99, 307-318.

AIS\&LUS (1971). Soil Survey Manual. All India Soil and Land Use survey (AIS\&LUS) publication, IARI, New Delhi: $121 \mathrm{p}$.

Black, C.A. (1965). Methods of Soil Analysis, Part I\&2 American Society of Agronomy, Madison, Wisconsin USA.

Jackson, M.L. (1967). Soil Chemical Analysis, Prentice Hall India Pvt. Ltd., New Delhi. 
Katyal, J.C., and Randhawa N.S. (1983). Secondary micronutrients: Research gaps and future needs. In Micronutrients. FAO Fertilizer and Plantation bulletin, Rome 5, p-92.

Klingebiel, A.A., and Montgomery, P.H. (1961). Land Capability Classification, Agriculture Handbook 210, Soil Conservation Service, USDA. Washington, D.C.: 105-108.

Lindsay, W.L., and Norvell, W.A. (1978). Development of DTPA soil test zinc, iron, manganese and copper. Soil Science Society of America Journal 42, 421-448.

Nagaraju, M.S.S., Nirmal-Kumar, Srivastava, R., and Das, S.N. (2014). Cadastral-level soil mapping in basaltic terrain using Cartosat-1-derived products. International Journal of Remote Sensing 35, 3764-3781.

NBSS\&LUP (1994). Soil-site suitability criteria for different crops. In: Proceedings of National Meet on soil- site suitability criteria for different crops. Feb. 7-8, 31p.

Pachpor, S.D., Nagaraju, M.S.S., Rajeev Srivastava, Barthwal, A.K., Nasre R.A., and Mohekar, D.S. (2012). Characterization and evaluation of land resources for management of Savli microwatershed in Wardha district of Maharashtra using geospatial technologies. Agropedology 22, 8-17.
Patil, Girish B., Nagaraju, M.S.S. Jagdish Prasad and Rajeev Srivastava (2010). Characterization and evaluation and mapping of land resources in Lendi watershed, Chandrapur district of Maharashtra using Remote Sensing and GIS. Journal of the Indian Society of Soil Science 58, 442-448.

Rao, A.P., Vara Prasad, Naidu, M.V.S., Ramavatharam N., and Rama, Rao G. (2008). Characterization, classification and evaluation of soils on different landforms in Ramachandrapuram Mandal of Chittoor district in Andhra Pradesh for sustainable land use planning. Journal of the Indian Society of Soil Science 56, 23-33.

Soil Survey Division Staff (2000). Soil Survey Manual, Handbook No.18, USDA, Washington, D.C.

Soil Survey Staff (2003). 'Keys to Soil Taxonomy', $9^{\text {th }}$ Edition, USDA, NRCS: Washington, D.C.

Srivastava, R., and R. K. Saxena (2004). Technique of large-scale soil mapping in basaltic terrain using satellite remote sensing data. International Journal of Remote Sensing 25, 679-688.

Takkar, P.N., Chhibba I.M., and Mehta, S.K. (1989). Twenty years of coordinated research on micronutrients in soil and plant. Bull., Indian Institute of Soil Science, Bhopal, 75p.

Received: March, 2018 Accepted: June, 2018 